\section{JURNAL PENGABDIAN PADA MASYARAKAT}

ISSN 2540-8739 (print) || ISSN 2540-8747 (online)

LEMBAGA PENELITIAN, PENGABDIAN, DAN PENGEMBANGAN MASYARAKAT UNIVERSITAS MATHLA'UL ANWAR BANTEN

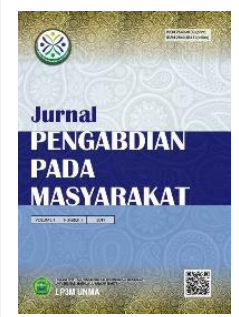

\title{
Interaksi Sosial Mahasiswa Kelompok 52 KKN-TT dalam Upaya Pemberdayaan Potensi Masyarakat di Desa Cibeber I, Kecamatan Leuwiliang, Kabupaten Bogor
}

\author{
Arief Goeritno ${ }^{1}$, Prawitra Azhari Robby ${ }^{2}$, Pratiwi $^{3}$, Widdy Tanzila ${ }^{4}$ \\ 1,2,3,4 Universitas Ibn Khaldun Bogor
}

\begin{tabular}{ll}
\hline Article History & ABSTRACT \\
\hline Received 11.12.2018 & SOCIAL INTERACTION OF THE STUDENTS ON GROUP 52 OF KKN-TT \\
Received in revised form & FOR EMPOWERMENT EFFORTS OF THE COMMUNITY POTENCY IN \\
Accepted 01.04.2019 & CIBEBER I VILLAGE, LEUWILIANG, BOGOR. Group 52 of KKN-TT was one \\
Available online 10.04.2019 & of the groups in the community service program held by the Bogor Ibn \\
& Khadun University in the City of Bogor. The Group 52 of KKN-TT activity \\
& was devoted to communities in Cibeber I Village, Leuwiliang, Bogor with \\
& three main programs and three supporting programs. The main programs \\
& cover the fields of formal and non-formal teaching, health and environment, \\
& and religion, while supporting programs include the economic field, the use \\
& of information technology, and relations in society. The six fields in the work \\
& program consist of fifteen types of planned and scheduled activities. Fifteen \\
& types of activities are a form of social interaction between students on Group \\
& 52 of KKN-TT and community in a potency of empower of the community. \\
& The achievement of all activities ranges from 80\% to 100\% with a number of \\
impacts on the community, in the form of long-term benefits. & \\
& Keywords: Community Potency, Empowerment Efforts, KKN, Leuwiliang, \\
& Social interaction.
\end{tabular}

DOI: $10.30653 / 002.201941 .98$

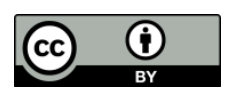

This is an open access article distributed under the terms of the Creative Commons Attribution 4.0 International License, which permits unrestricted use, distribution, and reproduction in any medium, provided the original work is properly cited. @ 2019 Arief Goeritno, Prawitra Azhari Robby, Pratiwi, Widdy Tanzila.

\section{PENDAHULUAN}

Interaksi sosial kelompok pendamping terhadap masyarakat sasaran merupakan upaya untuk pembangunan kembali daya pada masyarakat sasaran, melalui pendorongan, pemberian motivasi, dan pembangkitan kesadaran terhadap potensi yang dimiliki dan upaya untuk pengembangannya yang dikenal dengan istilah pemberdayaan. Indikasi terjadinya ketidakberdayaan masyarakat dalam menghadapi perubahan dan permasalahan terakumulasi dan menimbulkan frustrasi sosial, terlihat dengan semakin luasnya keresahan sosial (social unrest), kerusuhan atau kekerasan (riot), dan kemunculan

${ }^{1}$ Corresponding author: Program Studi Teknik Elektro, FTS Universitas Ibn Khaldun Bogor; Jl. K.H. Sholeh Iskandar km.2, Kedung Badak, Tanah Sareal, Kota Bogor, Jawa Barat; Email: arief.goeritno@uika-bogor.ac.id 
gejala disintegrasi sosial (Goeritno et al, 2003). Orientasi pemberdayaan (empowerment) haruslah berujud bantuan kepada masyarakat sasaran, agar mampu untuk pengembangan diri atas dasar inovasi-inovasi yang ada, ditetapkan secara partisipatoris, dengan metode pendekatan yang berorientasi pada kebutuhan masyarakat sasaran, dan hal-hal yang bersifat praktis, baik dalam bentuk layanan individu maupun kelompok. Peran kelompok pendamping (petugas pemberdayaan masyarakat) sebagai outsider people, berfungsi sebagai konsultan, peran pembimbingan, dan peran penyampai informasi (Karsidi, 2002; Karsidi, 2007). Berdasarkan pengalaman ditunjukkan, bahwa peranserta kelompok sasaran (masyarakat sasaran) harus sangat dominan, agar masyarakat sasaran tidak terpinggirkan dari proses pengupayaan kesejahteraan. Dalam arti luas, ketika peran penguasa sangat dominan dan peranserta masyarakat dipandang sebagai kewajiban, maka masyarakat justru termarjinalisasi. Bertitik tolak kepada setiap manusia atau masyarakat dengan potensi yang dapat dikembangkan, maka tidak terdapat masyarakat yang sama sekali tanpa daya.

Konsepsi atau istilah pemberdayaan dalam banyak kegiatan dan program aksi diarahkan kepada muara yang relatif sama, yaitu pembuatan sasaran, agar masyarakat berkemampuan "berdaya", sehingga masyarakat sasaran terangkat dari keterpurukannya. Dalam konsep asli, pemberdayaan masyarakat lebih difokuskan kepada nuansa dimana masyarakat sasaran dapat diposisikan terlibat aktif dalam proses kegiatan. Konsep pemberdayaan dalam wacana pembangunan selalu dihubungkan dengan konsep mandiri, partisipasi, jaringan kerja, dan keadilan yang secara prinsip diletakkan kepada kekuatan individu dan sosial (Hikmat, 2001). Tinjauan tiga sudut pandang dalam pemberdayaan masyarakat (Kartasasmita, 1997), yaitu (1) penciptaan suasana atau iklim untuk pengembangan potensi masyarakat (enabling), (2) perkuatan potensi atau daya yang dimiliki masyarakat (empowering), dan (3) perlindungan dari perlemahan terhadap yang lemah, agar tidak bertambah menjadi lemah. Kegiatan pemberdayaan masyarakat harus mampu dengan pengembangan teknik-teknik pendidikan tertentu yang imajinatif untuk penggugahan kesadaran masyarakat (Karsidi, 2002; Karsidi, 2007).

Desa Cibeber I merupakan salah satu desa di Kecamatan Leuwiliang, Kabupaten Bogor. Tingkat pendidikan di wilayah ini terbilang masih cukup rendah, dimana sebagian penduduk usia lanjut hanya berpendidikan Sekolah Dasar (SD), sedangkan para pemuda hanya dengan pendidikan hingga jenjang Sekolah Menengah Pertama (SMP) atau Sekolah Menengah Atas (SMA). Faktor ekonomi masih menjadi faktor penentu dalam penyadaran kesadaran masyarakat terhadap betapa pentingnya pendidikan untuk masa depan. Dilain pihak, pemanfaatan potensi alam yang ada dengan menjadikannya sebagai penyokong perekonomian masyarakat. Sejumlah potensi alam yang terdapat di Desa Cibeber I, anatara lain daerah pesawahan dan daerah perkebunan yang cukup luas, juga terdapat industri rumahan dengan produksi batu bata merah. Potensi tersebut menjadi sarana pekerjaan untuk masyarakat Desa Cibeber I, karena keberadaan Desa Cibeber I dengan luas wilayah 616,695 hektar dengan luas persawahan berkisar 105,359 hektar dan luas perkarangan berkisar 19 hektar yang secara umum merupakan daerah daratan dan sebagian kecil perbukitan dengan ketinggian antara 500-700 meter di atas permukaan air laut, dan bersuhu rata-rata $32^{\circ} \mathrm{C}$ (Ma'mun, 2014).

Berdasarkan uraian-uraian tersebut, maka dibuat program kerja untuk dukungan terhadap interaksi sosial sejumlah mahasiswa yang tergabung dalam Kelompok 52 Kuliah Kerja Nyata Tematik Terintegrasi (KKN-TT) Universitas Ibn Khaldun (UIKA) Bogor dengan masyarakat sasaran di Desa Cibeber I, Kecamatan Leuwiliang, Kabupaten Bogor. 
Interaksi sosial mahasiswa Kelompok 52 KKN-TT UIKA Bogor tahun 2018 dilakukan dalam bentuk berbagai kegiatan yang terobservasi dan terencana melalui peran partisipastif dan komunikatif dengan perangkat desa dan tokoh-tokoh masyarakat. Jenis kegiatan interaksi sosial mahasiswa, meliputi program pokok dan penunjang. Program pokok meliputi bidangn pengajaran formal dan non-formal, kesehatan dan lingkungan, dan keagamaan, sedangkan program penunjang meliputi bidang ekonomi, pemanfaatan teknologi informatika, dan hubungan dalam masyarakat.

Makalah ini bertujuan untuk penyampaian informasi tentang kegiatan mahasiswa Kelompok 52 dalam program pokok dan penunjang saat pelaksanaan KKN-TT tahun 2018 yang meliputi (1) partisipasi masyarakat dalam kegiatan dan langkah evaluasi terhadap pelaksanaan program dan (2) capaian program kerja dan dampak kegiatan bagi masyarakat. Program pokok meliputi (a) bidang pengajaran di pendidikan formal dan non-formal, berupa pengajaran di Madrasah Ibtidaiyyah (MI) dan penyelenggaraan bimbingan belajar; (b) bidang kesehatan dan lingkungan, berupa bantuan tenaga pada Pos Kesehatan Desa (Poskesdes), keikutsertaan dalam kerja bakti kebersihan pada masjid, keikutsertaan pada pemberian vitamin A dan imunisasi, keikutsertaan pada jalan sehat, dan keikutsertaan pada penyuluhan pola hidup bersih dan sehat; dan (c) bidang keagamaan berupa keikutsertaan dalam pengajaran pada Taman Pendidikan Al-Qur'an, pengajaran tentang tata cara dan praktik fiqh ibadah, dan pengenalan dan pengobatan bekam sunnah. Program penunjang meliputi (a) bidang ekonomi berupa keikutsertaan pada penyuluhan menabung sejak dini dan pemanfaatan sampah botol plastik, (b) bidang pemanfaatan teknologi informatika berupa update dengan Google Maps untuk lokasi Kantor Desa Cibeber I, dan (c) bidang hubungan dalam masyarakat berupa keikutsertaan dalam acara peringatan dan perayaan HUT ke-73 RI dan gerakan tanam pohon.

\section{METODE PELAKSANAAN}

\section{Tahapan Pelaksanaan}

Tahapan pelaksanaan untuk kegiatan KKN-TT dari Kelompok 52 dibuat dalam bentuk bagan. Bagan tahapan pelaksanaan kegiatan, seperti situnjukkan pada Gambar 1.

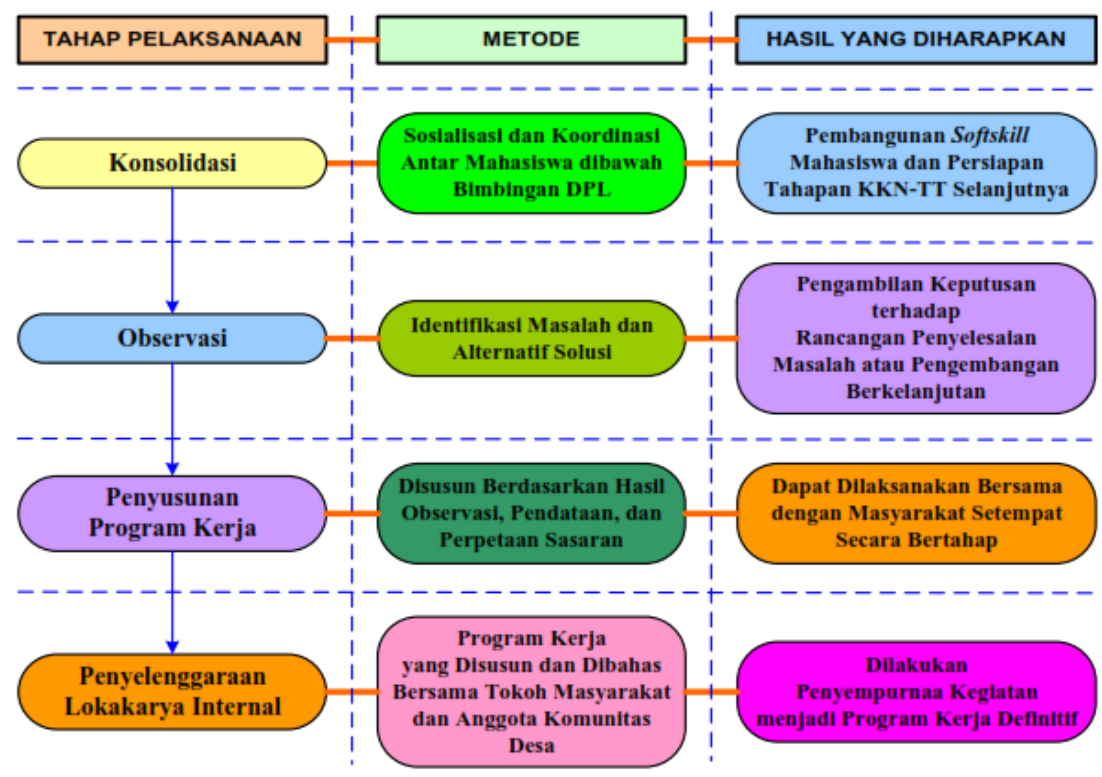

Gambar 1. Bagan tahapan pelaksanaan kegiatan 
Berdasarkan bagan tahapan pelaksanaan kegiatan, Kelompok 52 pada KKN-TT tahun 2018 di Desa Cibeber I dalam bentuk matrik. Jadwal kegiatan Kelompok 52 KKNTT, seperti ditunjukkan pada Tabel 1.

Tabel 1 Jadwal kegiatan Kelompok 52 KKN-TT

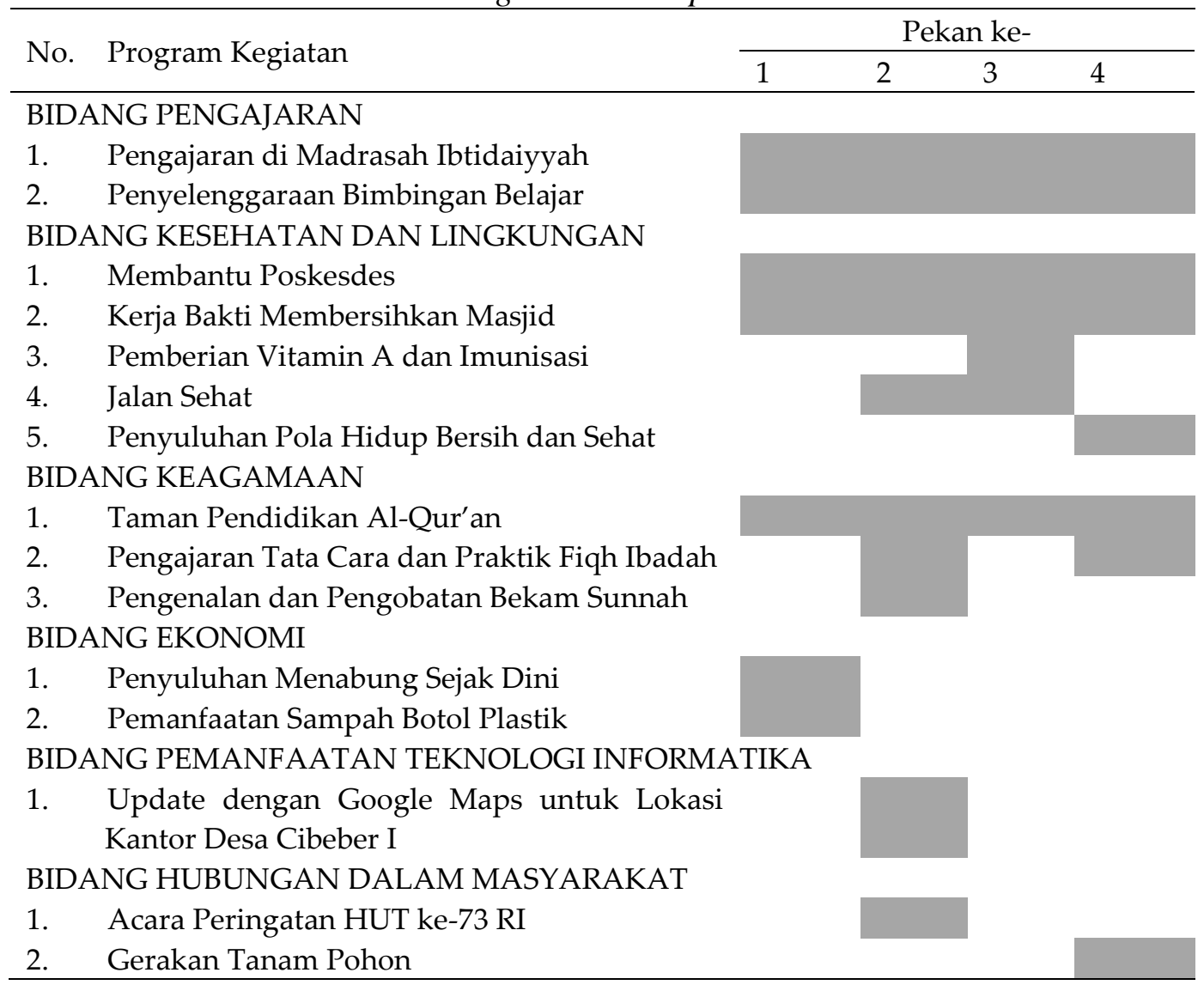

\section{Alasan Pemilihan Program Kegiatan}

Pemilihan terhadap jenis program utama dan penunjang untuk kegiatan didasari oleh situasi dan kondisi yang ditemui saat survei awal dan pelaksanaan KKN-TT oleh Kelompok 52. Pemilihan terhadap Bidang Pengajaran pada Pendidikan Formal dan Nonformal, didasari oleh fasilitas pengajaran dalam pendidikan yang sangat minim, tingkat pendidikan yang rendah, dan kesadaran terhadap pendidikan sangar rendah. Pendidikan merupakan modal yang sangat penting dalam peningkatan perekonomian, karena sumberdaya manusia yang berkualitas tercipta dari pendidikan yang berkualitas pula. Sumberdaya manusia yang berpendidikan berpotensi untuk lebih melek informasi dan kemampuan untuk pengubahan segala potensi menjadi peluang. Keberadaan sejumlah sekolah setingkat SD sampai SMA dan desa yang penuh sumberdaya yang berlimpah, justru kekurangan fasilitas pendidikan. Di Desa Cibeber 1 untuk pendidikan jenjang SMP tidak dengan fasilitas yang memadai, ruangan kelas harus digunakan bergantian dengan SD, sehingga suasana kelas tidak kondusif, dan tidak terdapat perpustakaan dan lapangan.

Tingkat pendidikan yang rendah, berakibat kepada kemampuan masyarakat untuk berinovasi, sulit dalam perolehan pekerjaan yang layak, penghambat dalam keikutsertaan 
dalam pemanfaatan kemajuan teknologi, kesulitan dalam pengelolaan sumberdaya alam, dan penemuan peluang usaha. Kesadaran terhadap pendidikan sangat rendah didasari oleh faktor ekonomi sebagai alasan utama untuk kelanjutan dalam pendidikan hingga ke perguruan tinggi. Peran orang tua pun ikut serta dalam penanaman dalam benak anak sedari kecil, bahwa mereka tidak sanggup untuk menyekolahkan hingga perguruan tinggi.

Pemilihan terhadap Bidang Kesehatan dan Lingkungan, didasari oleh kesadaran dalam penjagaan lingkungan dan hidup bersih sangat rendah dan kesulitan dalam perolehan air bersih. Masyarakat masih belum dapat dalam pengelolaan sampah dengan baik, hal ini didasari oleh semua sampah dibuang di pinggir kali dan pembakaran sampah yang dapat berakibat kepada peningkatan pencemaran dan perusakan terhadap kondisi kesehatan terutama organ pernapasan. Selain hal itu, kesadaran terhadap pola hidup sehat juga masih cukup rendah yang ditunjukkan dengan kebiasaan masyarakat dalam pencucian pakaian dan peralatan dapur, aktivitas mandi, dan buang hajat di sungai yang dipinggirnya tertumpuk sampah. Kesulitan dalam perolehan air bersih ditunjukkan di beberapa RW di Desa Cibeber 1, karena belum terdapat jaringan pipa air bersih dari PDAM, sehingga masyarakat sangat bergantung kepada air sumur. Air sumur yang diperoleh sangat keruh dan terkadang berbau besi. Kesulitan air bersih diperparah dengan keberadaan musim kemarau, sehingga mau tidak mau masyarakat dalam pemenuhan terhadap kebutuhan air sehari-hari diperoleh dari air sungai.

Pemilihan terhadap Bidang Keagamaan, didasari oleh keberadaan anak-anak Desa Cibeber 1 belum paham secara benar tata cara berwudhu dan sholat sesuai yang diajarkan oleh Nabi Muhammad shollalloohu 'alaihi wa sallam dan pengenalan dan pengobatan bekam sunnah, sedangkan pemilihan terhadap Bidang Ekonomi, han terhadap bidang ekonomi didasari oleh kelemahan struktur permodalan dan akses terhadap sumber permodalan. Modal merupakan faktor utama untuk permulaan suatu usaha, besar kecilnya usaha yang dibangun bergantung kepada modal yang dimiliki. Di Desa Cibeber I, sumber untuk perolehan pinjaman modal dikatakan cukup sulit. Keberadaan lokasi Kantor Desa Cibeber I yang belum terdeteksi oleh Google Map saat dilakukan observasi/survei awal merupakan alasan pemilihan kegiatan di Bidang Pemanfaatan Teknologi Informatika, sedangkan alasan pemilihan terhadap Bidang Hubungan dalam Masyarakat, didasari oleh hubungan antara masyarakat di Desa Cibeber I juga tampak begitu harmonis dan patut diteladani. sifat kekeluargaan tampak begitu kental terlihat di berbagai bidang, misalnya gotong royong pada acara Hari Ulang Tahun Kemerdekaan Republik Indonesia dan pada acara-acara besar lain.

\section{Metode Pendekatan}

Dalam pelaksanaan KKN-TT UIKA Bogor tahun 2018, metode Participatory Rural Appraisal (PRA) dan pendekatan sosial dipilih oleh Kelompok 52.

\section{Metode Participatory Rural Appraisal (PRA)}

Metode dengan perlibatan masyarakat mulai dari tahap perencanaan, pelaksanaan, pemanfaatan, dan evaluasi. Dalam metode PRA, dimungkinkan masyarakat desa saling berbagi, penambahan, dan analisis pengetahuan tentang kondisi lingkungannya dalam rangka pembuatan perencanaan dan tindakan. Metode PRA merupakan cara yang digunakan dalam pelaksanaan kajian untuk pemahaman keadaan atau kondisi desa dengan perlibatan dan partisipasi masyarakat, atau pengkajian atau penilaian terhadap keadaan desa secara partisipatif. 
Penggunaan metode $P R A$ bertujuan untuk dihasilkan rancangan program yang relevan dengan harapan dan keadaan masyarakat, agar terdapat kemampuan masyarakat dalam analisis keadaan diri dan diwujudkan dengan pelaksanaan perencanaan dan realisasi dapat berkembang, sehingga dapat dibuat program dan pelaksanaannya. Dalam kegiatan PRA ini, mahasiswa hanya sebagai fasilitator sekaligus motivator dan masyarakatlah sebagai pelaksananya.

\section{Pendekatan Sosial}

Dalam beberapa program kegiatan Kelompok $52 \mathrm{KKN}-\mathrm{TT}$ ini, dilakukan pendekatan sosial baik pada tahap perencanaan, pelaksanaan, maupun pada tahap evaluasi. Dalam tahap perencanaan, pendekatan sosial dilakukan dengan perlibatan masyarakat secara langsung maupun tidak langsung dalam penyusunan rencana atau program kegiatan kelompok 52 KKN-TT ini. Perlibatan (partisipasi) masyarakat dalam perencanaan, dapat teridentifikasi berbagai harapan (ekspektasi), kebutuhan, dan permasalahan nyata yang dihadapi masyarakat, sehingga dapat disusun action plan yang lebih tepat dan realistis. Semakin banyak masyarakat yang dilibatkan tentunya semakin baik. Di samping itu, keterlibatan masyarakat dalam perencanaan dapat membawa efek psikologis untuk sama-sama bertanggung jawab dalam implementasi rencana-rencana yang telah dibuat.

Pendekatan sosial dalam tahap pelaksanaan, terutama dilakukan oleh mahasiswa Kelompok 52 KKN-TT melalui penciptaan komunikasi dan hubungan sosial yang harmonis untuk secara bersama dalam setiap rencana yang telah disusun. Dibandingkan dengan tahapan KKN-TT lainnya, tahapan pelaksanaan inilah pendekatan sosial memegang peranan penting dan harus banyak dilakukan oleh para mahasiswa Kelompok KKN-TT. Pendekatan sosial dalam tahap evaluasi berkaitan erat dengan partisipasi masyarakat untuk pemberian data secara objektif atas kegagalan dan keberhasilan kegiatan Kelompok 52 KKN-TT.

\section{HASIL DAN PEMBAHASAN}

Partisipasi masyarakat dalam kegiatan ini, meliputi: 1) Penyiapan situasi dan kondisi terhadap masyarakat yang bersedia ikut serta dalam pembinaan, baik tentang pengajaran pada pendidikan, keagamaan, kesehatan dan lingkungan, perekonomian, teknologi pemanfaatan teknologi informatika, dan hubungan dalam masyarakat; 2) Kerja sama dalam perencanaan, pelaksanaan, pemanfaatan, dan evaluasi; 3) Penyiapan tempat pelaksanaan pembinaan dan aktivitas; dan 4) Masyarakat bekerja bersama untuk realisasikan program yang telah dibuat.

Evaluasi yang telah dilakukan terdiri atas evaluasi terhadap proses dan hasil. Evaluasi proses, terkait dengan perencangan, pembinaan, dan proses pelaksanaan. Evaluasi proses dilakukan setiap pekan bersama tokoh-tokoh masyarakat dan keorganisasian yang terdapat di Desa Cibeber I. Evaluasi hasil, dilaksanakan setelah kegiatan selesai setiap hari saat malam sebelum istirahat. Evaluasi hasil ditujukan untuk mengetahui sejauh mana program Kelompok $52 \mathrm{KKN}-\mathrm{TT}$ terlaksana.

Pelaksanaan program utama dan penunjang pada pelaksanaan KKN-TT UIKA Bogor tahun 2018 dimulai pada tanggal 07 Agustus sampai 07 September 2018. Kelompok 52 ditempatkan di Desa Cibeber I, Kecamatan Leuwiliang, Kabupaten Bogor. Berbagai permasalahan yang telah dipaparkan pada alasan pemilihan program di atas, maka dibuat rencana program kerja untuk ikut serta dalam pengurangan polemik-polemik dengan tujuan untuk pemberdayaan masyarakat Desa Cibeber I. 


\section{Bidang Pengajaran pada Pendidikan Formal dan Non-formal}

Pengajaran di Madrasah Ibtidaiyyah (MI)

Program ini dilaksanakan pada hari Selasa, 13 Agustus 2018 dan Kamis, 15 Agustus 2018. Berlokasi di Kampung Hegarmanah, Desa Cibeber I. Dalam pelaksanaannya, dibagi menjadi 3 tim dengan orientasi penanganan pada kelas rendah (kelas 1-3 SD), dilanjutkan dengan pengajaran di kelas lebih tinggi (kelas 4-6 SD). Tujuan program ini untuk bantuan terhadap guru di sekolah dalam pemberian materi pelajaran, karena kekurangan tenaga pengajar, sehingga para mahasiswa dapat implementasikan ilmu dan pengetahuan yang telah diperoleh dalam perkuliahan. Suasana kelas saat pengajaran di MI, seperti ditunjukkan pada Gambar 2.
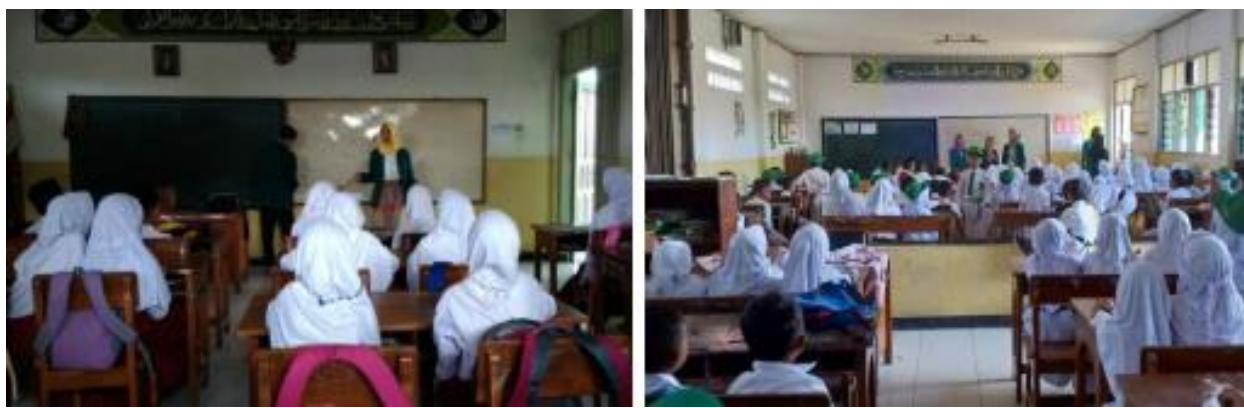

Gambar 2. Suasana kelas saat pengajaran di MI

Program terlaksana dengan hasil capaian sebesar 100 persen. Manfaat jangka panjang untuk para murid MI berupa perevitalisasian atau penghidupan kembali semangat belajar di sekolah.

\section{Penyelenggaraan Bimbingan Belajar}

Kegiatan bimbingan belajar dilaksanakan mulai hari Senin, 13 Agustus 2018 sampai Jum'at, 31 Agustus 2018. Pelaksanaan bimbingan belajar ini, untuk bantuan dalam pemahaman pelajaran yang dianggap sulit. Hasil yang diperoleh dari proses bimbingan belajar ini bagi siswa, yaitu perolehan pengetahuan baru tentang cara belajar efektif dan pengetahuan tentang belajar yang mudah dan menyenangkan. Selain itu, setiap selesai pengajaran para siswa dimotivasi. Suasana saat bimbingan belajar, seperti ditunjukkan pada Gambar 3.

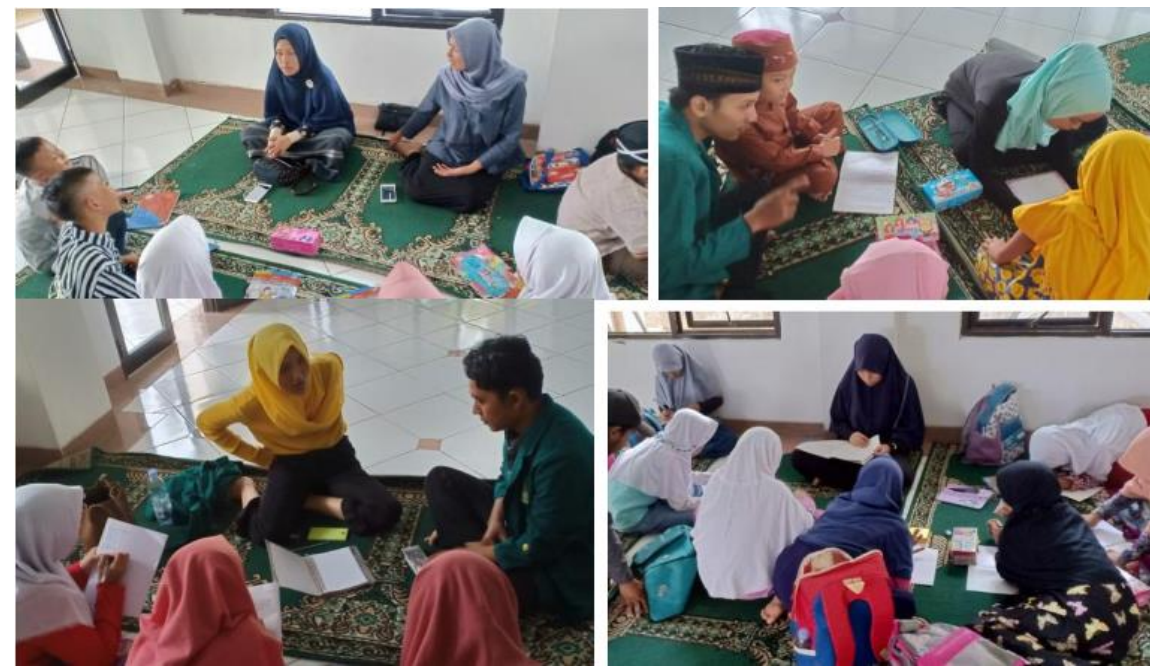

Gambar 3. Suasana saat Bimbingan Belajar 
Program bimbingan belajar ini dinyatakan berhasil dan sangat bermanfaat dengan capaian sebesar 100 persen. Dampak yang diharapkan berupa kebiasaan anak-anak untuk belajar bersama-sama dan pengurangan durasi bermain, dimana untuk peserta bimbingan belajar yang sudah berada di jenjang Madrasah Tsanawiyyah (MTs) dapat membimbing adik-adiknya yang di bawah tingkatan, seperti PAUD dan SD/MI.

\section{Bidang Kesehatan dan Lingkungan}

Bantuan Tenaga pada Poskesdes

Kegiatan Poskesdes dilakukan pada setiap hari kamis setiap pekannya di posyandu ROS 1, dimulai pada pukul 8 pagi. Kegiatan ini bertujuan untuk membantu tugas para kader serta tenaga kesehatan yang berperan dalam pelaksanaan poskesdes dan posyandu, baik itu dalam hal pendataan pasien dan peracikan atau pemberian obat, termasuk alur kefarmasian di Poskesdes tidak sesuai dengan standar mutu keselamatan pasien, sehingga kehadiran mahasiswa KKN-TT dengan perubahan berupa perbaikan alur di Poskesdes. Pelaksanaan peracikan obat untuk pasien, seperti ditunjukkan pada Gambar 4.
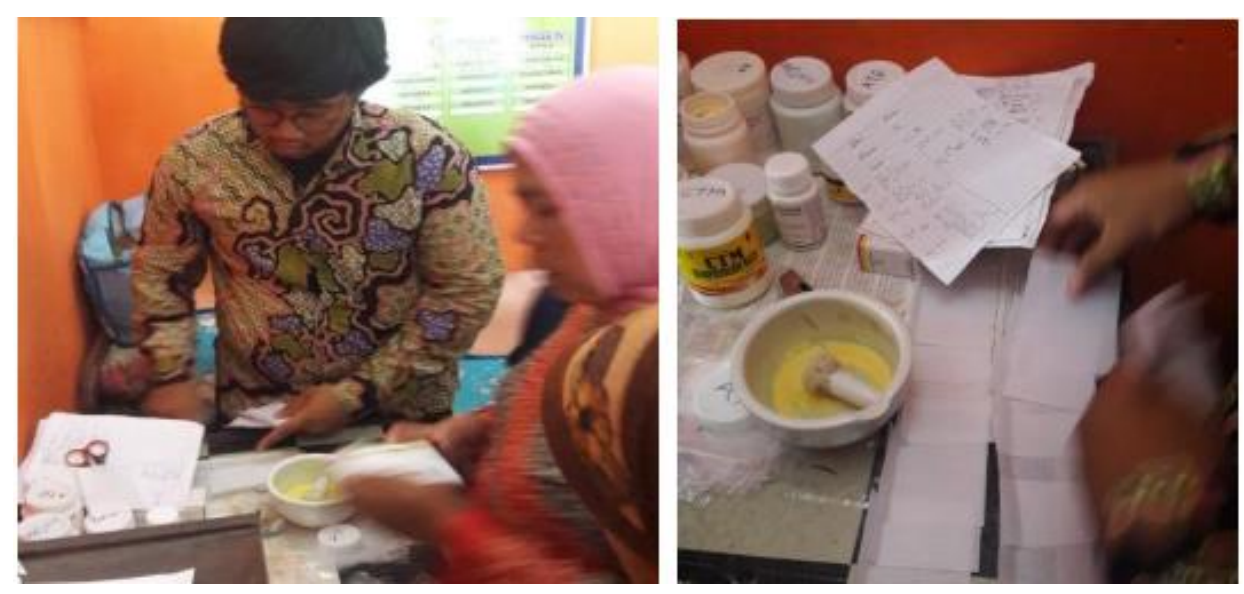

Gambar 4. Pelaksanaan Peracikan Obat untuk Pasien

Pencapaian dari program ini sebesar $80 \%$. Dampak jangka pendek yang dapat diperoleh masyarakat adalah waktu berobat di posyandu menjadi lebih cepat karena terdapat penambahan tenaga yang terlibat dalam proses yang lebih efisien. Dampak bagi kader dan petugas kesehatan berupa keterbantuan tugas kader dan petugas kesehatan dan efektivitas waktu yang digunakan untuk penanganan pasien yang datang. Dampak jangka panjang berupa keterjalinan silaturahmi yang kuat antara mahasiswa Kelompok $52 \mathrm{KKN}-\mathrm{TT}$ dan petugas kader dari posyandu, karena rasa kesamaan profesi dalam pengabdian pada masyarakat.

\section{Keikutsertaan Kerja Bakti Kebersihan Masjid}

Dilakukan di Masjid Jami' Darut Taqwa pada hari jumat di setiap pekannya. Kegiatan ini bertujuan untuk penjagaan terhadap keindahan masjid dan kenyamanan masyarakat yang beribadah ataupun kegiatan di perkarangan masjid. Tujuan lain dari kegiatan tersebut kerja bakti kebersihan pada masjid ini, adalah pembangunan rasa peduli masyarakat terhadap kebersihan lingkungan. Suasana saat pelaksanaan kerja bakti kebersihan pada masjid, seperti ditunjukkan pada Gambar 5. 

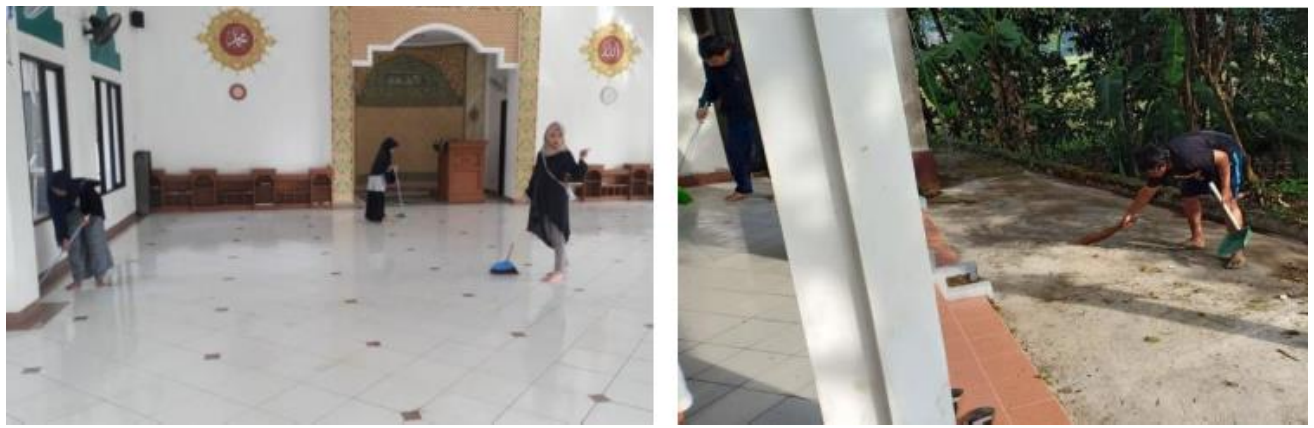

Gambar 5. Suasana saat Pelaksanaan Kerja Bakti Kebersihan pada Masjid

Pencapaian program ini sebesar $80 \%$. Dampak yang diharapkan dari kegiatan ini, berupa timbul kesadaran pada masyarakat, bahwa kebersihan lingkungan masjid bukan hanya tugas DKM saja, tetapi juga tanggung jawab bersama.

\section{Keikutsertaan Pada Pemberian Vitamin A dan Imunisasi}

Kegiatan ini dilaksanakan pada hari Kamis, 23 Agustus 2018. Selain pemberian vitamin A dan imunisasi campak, kami juga membagikan bubur kacang hijau untuk balita. Kegiatan ini bertujuan untuk membantu tugas para kader serta tenaga kesehatan yang berperan dalam pelaksanaan, baik itu dalam hal pendataan balita, pemberian vitamin A, dan imunisasi campak. Pelaksanaan pemberian vitamin A dan imunisasi campak, seperti ditunjukkan pada Gambar 6.

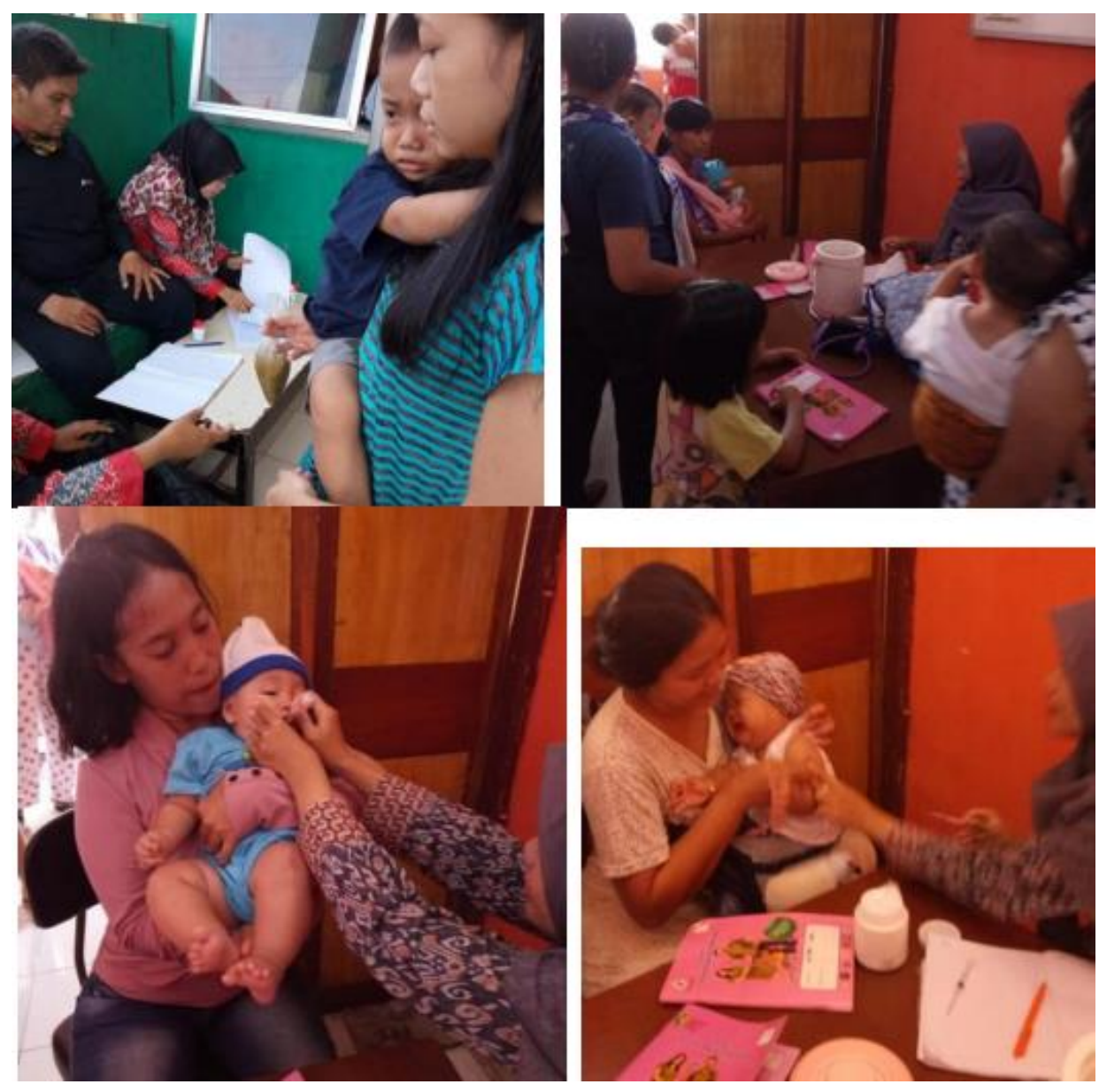

Gambar 6. Pelaksanaan Pemberian Vitamin A dan İmunisasi Campak 
Pencapaian dari program ini sebesar 80 persen. Dampak jangka panjang yang dapat diperoleh masyarakat berupa pencegahan penyakit campak dikemudian hari dan pemantauan perkembangan tubuh balita.

Keikutsertaan dalam Jalan Sehat

Jalan sehat digelar dalam rangka peringatan HUT ke-73 RI yang dilaksanakan pada hari Ahad, 19 Agustus 2018 dan 26 Agustus 2018. Tujuan kegiatan ini untuk ajak serta masyarakat dalam hidup lebih sehat dan gemar berolahraga. Jalan sehat ini mengitari sebagian Desa Cibeber I, dimulai Masjid Jami' Darut Taqwa dan berakhir Lapangan Bola Kampung Hegarsari. Suasana saat pergelaran jalan sehat, seperti ditunjukkan pada Gambar 7.
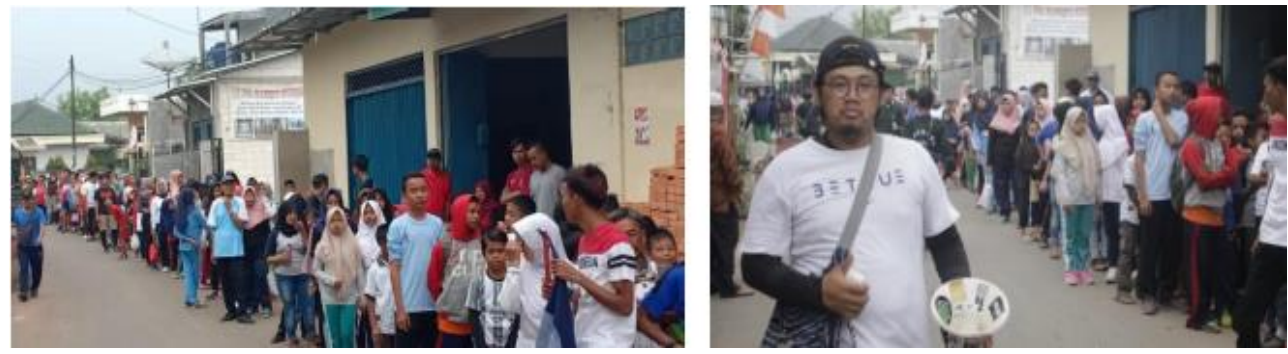

Gambar 7. Suasana saat Pergelaran Jalan Sehat

Pencapaian program ini sebesar 80 persen. Dampak yang diharapkan pada masyarakat, yaitu pembentukan mindset, bahwa Berjalan untuk peningkatan sirkulasi darah, karena jantung berdebar dan efektif perkuat terhadap sistem kekebalan tubuh. Selain itu, kegiatan ini untuk penumbuhkembang rasa kerukunan dan kebersamaan bagi masyarakat Desa Cibeber I, karena jarak antar dusun relatif berjauhan.

\section{Keikutsertaan Pada Penyuluhan Pola Hidup Bersih dan Sehat}

Kegiatan penyuluhan ini dilakukan di MI dengan perlibatan murid kelas 1-6. Kegiatan ini bertujuan untuk pemberian ilmu dan pengertian tentang kepentingan dalam penjagaan perilaku hidup bersih dan sehat, dan tata cara atau langkah-langkah pencucian tangan yang benar. Pemberian penyuluhan dalam bentuk presentasi visual, dan penjelasan secara lisan atau interaksi langsung. Pencapaian dari program ini sebesar 90 persen. Suasana saat penyuluhan pola hidup bersih dan sehat, seperti ditunjukkan pada Gambar 8.
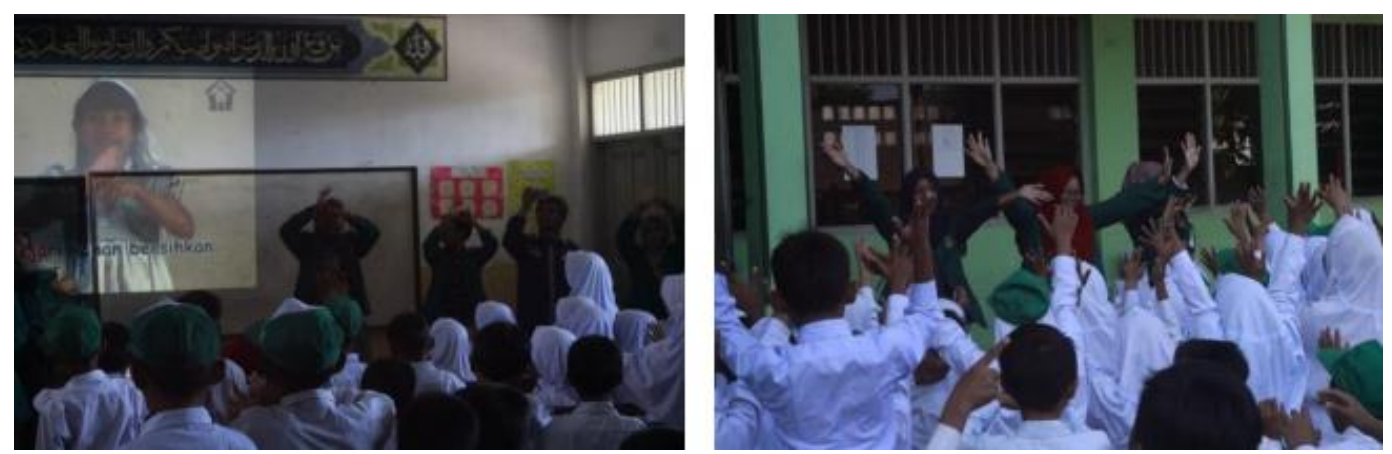

Gambar 8. Suasana saat Penyuluhan Pola Hidup Bersih dan Sehat

Dampak yang diharapkan, para murid peroleh pengetahuan tentang perilaku hidup bersih dan sehat dan tepat waktu dan penerapannya di kehidupan sehari-hari. Dampak jangka bagi para murid berupa kebiasaan praktik dan penerapan perilaku hidup bersih 
dan sehat dengan harapan dapat untuk pengurangan atau penekanan angka persakitan, karena gaya hidup kurang baik.

\section{Bidang Keagamaan}

Pengajaran pada Taman Pendidikan Al-Qur'an (TPA)

Program ini mulai dilaksanakan pada hari Jum'at, 10 Agustus 2018 setelah ba'da Maghrib, bertempat di rumah Bapak Yahya selaku Pengurus DKM Masjid Darut Taqwa. Foto bersama di rumah Bapak Yahya selaku Pengurus DKM Darut Taqwa, seperti ditunjukkan pada Gambar 9.

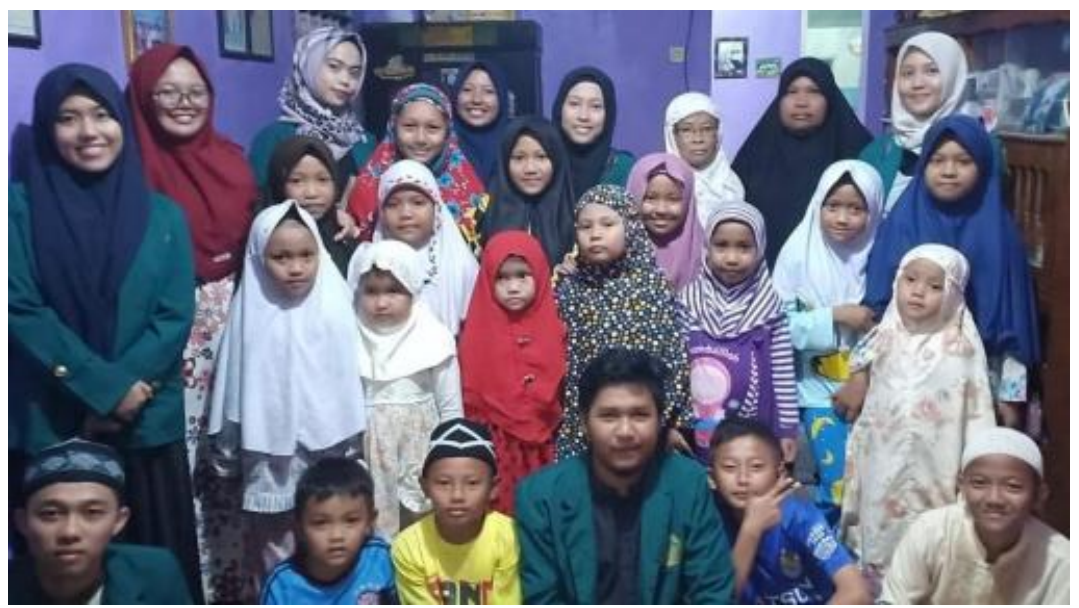

Gambar 9. Foto bersama di rumah Bapak Yahya selaku Pengurus DKM Darut Taqwa

Program ini merupakan bentuk bantuan terhadap istri Bapak Yahya yang seorang diri dalam pengajaran ke 30 anak. Dalam program ini diajarkan beberapa pelajaran diantaranya cara pembacaan Al-Qur'an yang tartil dan penghafalan terhadap 99 asmaul husna. Suasana pengajaran baca Al-Qur'an, seperti ditunjukkan pada Gambar 10.

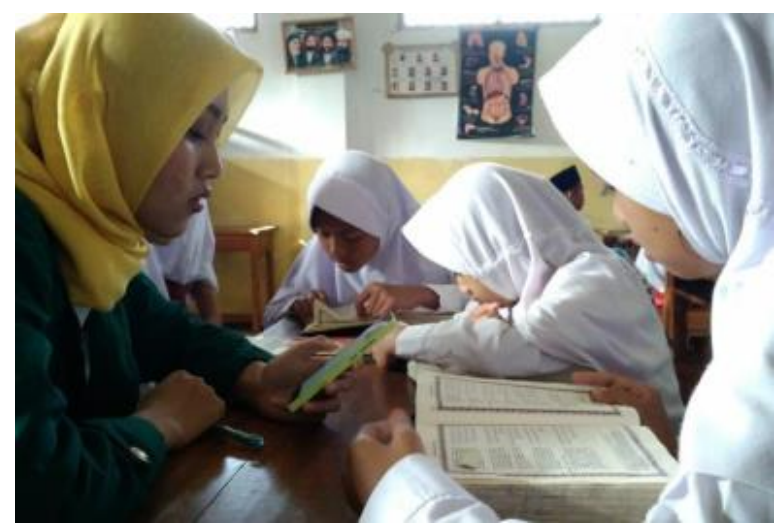

Gambar 10. Suasana pengajaran baca Al-Qur'an

Program ini bertujuan agar anak-anak TPA dapat lancar dalam pembacaan AlQur'an dengan baik sesuai kaidah tajwid. Penghafalan terhadap asmaul husna dilakukan dengan cara hafalan yang menyenangkan, yaitu dengan nada yang indah ketika menghafalnya. Capaian program ini sebesar 85 persen. Dampak yang dirasakan berupa beberapa anak sudah mulai dengan bacaan Al-Qur'an yang tartil sesuai dengan kaidah tajwid dan anak-anak sudah hafal 99 Asmaul Husna tanpa harus melihat kembali buku yang sebelumnya dilakukan. 


\section{Pengajaran Pada Tata Cara dan Praktik Fiqh Ibadah}

Fiqh ibadah yang diajarkan meliputi fiqh wudhu dan sholat. Pengajaran fiqh wudhu dilaksanakan hari Selasa, 14 Agustus 2018, sedangkan fiqh sholat dilaksanakan hari Sabtu, 1 September 2018 bertempat di Masjid Darut Taqwa. Program ini bertujuan, agar masyarakat atau khususnya anak-anak tingkat SD dan SMP Kampung Hegarmanah paham benar bagaimana praktik berwudhu dan sholat secara benar dan tertib. Mahasiswa sebagai instruktur dengan penyampaian teori, kemudian anak-anak praktik berwudhu dan sholat dengan pengawasan langsung, agar tidak lupa dengan yang sudah diajarkan. Suasana praktik berwudhu, seperti ditunjukkan pada Gambar 11.
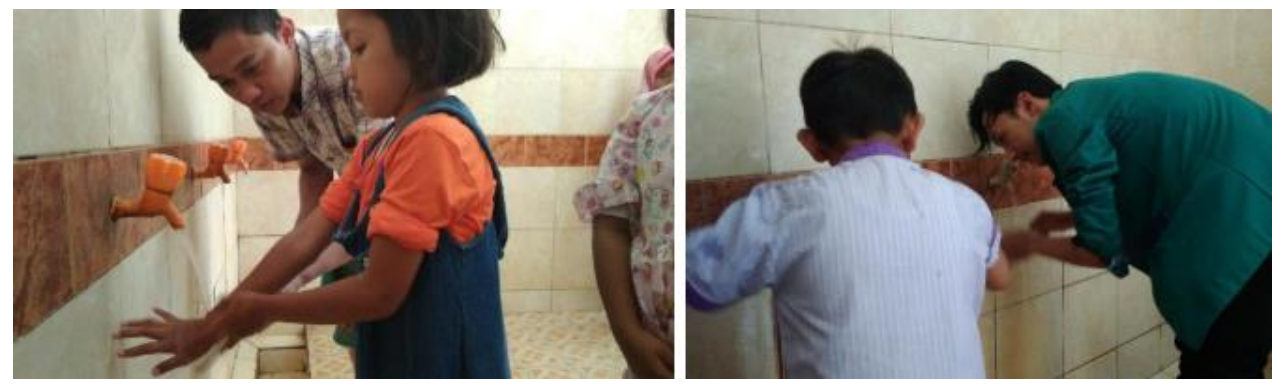

Gambar 11. Suasana Praktik Berwudhu

Tindak lanjut terhadap praktik berwudhu sesuai tuntunan, maka dilakukan penempelan poster tata cara wudhu dan sholat di dinding masjid. Pencapaian dari program ini sebesar $95 \%$. Dampak yang terlihat, sejumlah orang tua telah mendapati anak-anaknya sudah paham dalam praktik wudhu dan sholat sesuai ajaran Nabi Muhammad shollalloohu 'alaihi wa sallam dan paham tentang macam-macam perbedaan yang ada. Bagi orang tua atau anak lain yang tidak sempat ikut serta, mereka juga dapat melihatnya dari poster yang ditempel di dinding Masjid Jami Darut Taqwa.

\section{Pengenalan dan Pengobatan Bekam Sunnah}

Kegiatan ini dilaksanakan pada hari Sabtu, 18 Agustus 2018 bertempat di Masjid Jami Darut Taqwa untuk laki-laki dan Klinik Bidan Nyonya Peni untuk perempuan dengan tujuan untuk pengenalan pengobatan sunnah sesuai syariat Islam kepada masyarakat dan pemanasan aliran energi dalam darah yang dapat menghilangkan hawa dingin, kelembaban, dan racun yang disebabkan penumpukkan obat kimiawi. Kegiatan pengenalan dan pengobatan bekam sunnah, seperti ditunjukkan pada Gambar 12.
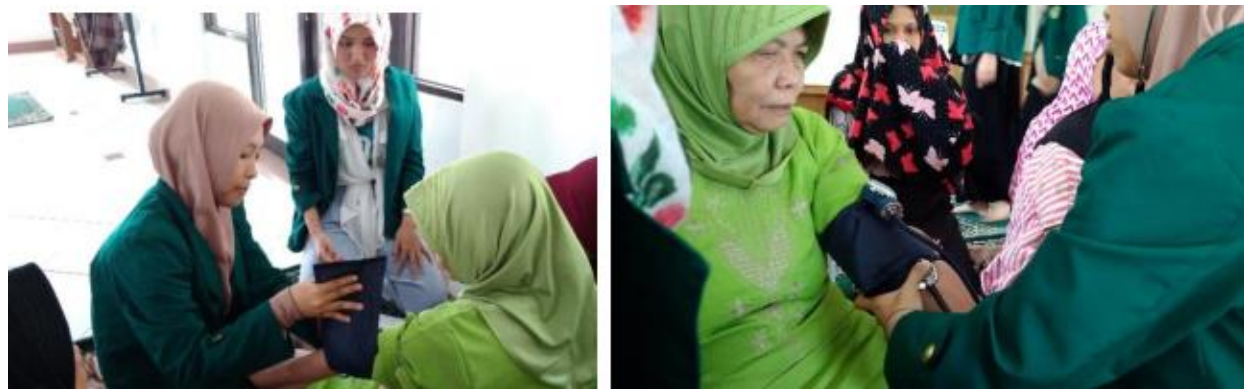

Gambar 12. Kegiatan Pengenalan dan Pengobatan Bekam Sunnah

Pencapaian program ini sebesar 100 persen. Dampak yang diharapkan, timbul pemahaman masyarakat, bahwa pengobatan sunnah tidak kalah dengan pengobatan kimiawi, dan kesadaran dalam penjagaan kesehatan lebih penting daripada pengobatan. 


\section{Bidang Ekonomi}

\section{Keikutsertaan dalam Penyuluhan Menabung Sejak Dini}

Kegiatan ini dilaksanakan hari Kamis, 15 Agustus 2018 bertempat di MI dengan perlibatan siswa-siswa kelas 4-6. Target pencapaian kegiatan ini berupa motivasi kepada anak-anak untuk menabung dan mengerti tentang arti penting penabungan untuk masa depan. Capaian kegiatan ini sebesar 100\%. Dampak yang timbul berupa kesadaran para murid tentang makna penting menabung untuk masa depan, terbiasa untuk hidup hemat, dan mampu untuk pengelolaan keuangan dimasa depan.

\section{Keikutsertaan dalam penyuluhan pemanfaatan sampah botol plastik}

Pelaksanaan kegiatan ini bersamaan dengan kegiatan penyuluhan menabung sejak dini. Kegiatan ini berupa proses pembuatan kerajinan celengan dengan bahan utama berupa botol bekas. Tujuan kegiatan ini untuk pengajaran tentang arti penting pendaura ulang barang-barang bekas di lingkungan sekitar dan pengajaran tentang kreativitas, inovasi, dan pola pikir terbuka terhadap barang yang tampak seperti sampah, tetapi masih punya kegunaan lebih. Pencapaian program ini sebesar $100 \%$. Kegiatan pemanfaatan sampah botol plastik, seperti ditunjukkan pada Gambar 13.
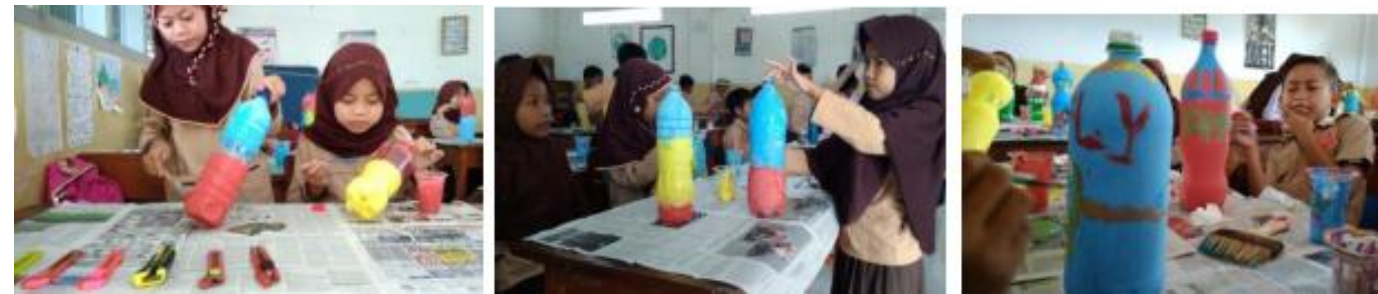

Gambar 13. Kegiatan Pemanfaatan Sampah Botol Plastik

Pengenalan kreativitas untuk pengubahan botol plastik menjadi celengan, para murid dapat kelola limbah botol plastik menjadi barang yang lebih bernilai. Dampak jangka panjang yang dapat ditimbulkan berupa kebersihan lingkungan.

\section{Bidang Pemanfaatan Teknologi Informatika}

Program kegiatan ini dilakukan dengan didasari oleh kondisi saat dlakukan observasi atau survei tentang lokasi untuk tujuan ke Kantor Desa Cibeber I tidak terdeteksi dalam Google Maps. Penunjukan pada Google Maps sebelum dan sesudah dilakukan peng-update-an, seperti ditunjukkan pada Gambar 14.

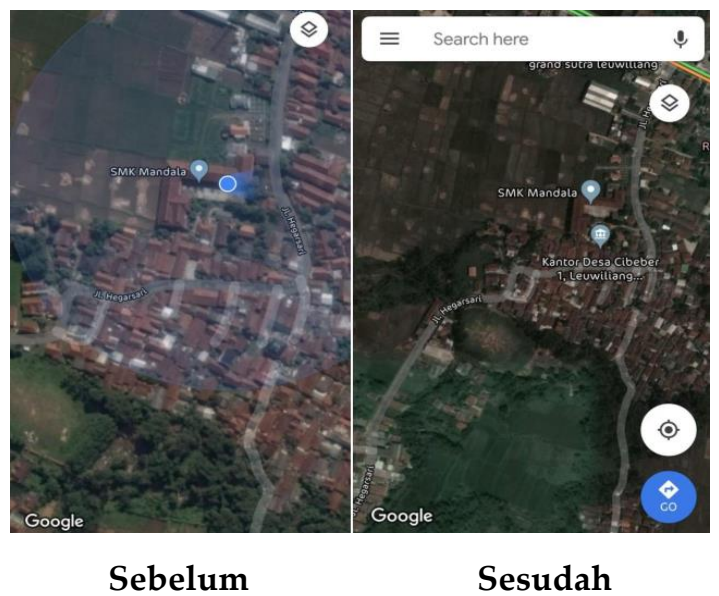

Gambar 14. Penunjukan Pada Google Maps Sebelum dan Sesudah dilakukan Peng-update-an 
Pengajuan titik lokasi pada pihak Google dengan harapan warga pendatang atau wisatawan dapat dengan mudah mengetahui lokasi Kantor Desa Cibeber I. Kegiatan ini berupa peng- update-an dengan Google Maps untuk lokasi Kantor Desa Cibeber I yang dilaksanakan hari Senin, 13 Agustus 2018. Capaian kegiatan ini sebesar 100\%. Pengupdate-an dengan Google Maps pada lokasi Kantor Desa Cibeber I, bermanfaat untuk kemudahan warga pendatang atau wisatawan dalam tujuan Kantor Desa Cibeber I, termasuk sebagai langkah nyata untuk keterwujudan Desa Cibeber I sebagai desa potensial yang diarahkan menjadi Desa Pusat Pertumbuhan (DPP).

\section{Bidang Hubungan dalam Masyarakat}

\section{Keikutsertaan dalam Acara Peringatan dan Perayaan HUT Ke-73 RI}

Kegiatan ini dilakukan untuk peringatan dan perayaan dalam rangkan Hari Ulang Tahun Kemerdekaan ke-73 Republik Indonesia dan untuk penumbuhan rasa kebersamaan, solidaritas, dan semangat patrotisme dan nasionalisme. Selain kegiatan itu, diadakan santunan anak yatim sebagai wujud kepedulian terhadap sesama di hari besar Indonesia. Kegiatan ini untuk penumbuhkembang rasa kedekatan antar masyarakat di Desa Cibeber I dengan mahasiswa Kelompok 52 KKN-TT. Capaian kegiatan ini sebesar $100 \%$.

Rasa kebersamaan dan solidaritas antar warga meningkat, tingkat nasionalis dan patriotisme di masyarakat Desa Cibeber I juga meningkat. Selain itu kedekatan dan tali silaturahmi antar masyarakat dan Mahasiswa KKN-TT 52 dapat terjalin dengan baik. Dampak santunan anak yatim ialah membuka mata masyarakat akan kepedulian bagi anak-anak yang telah ditinggalkan sosok ayah sedari kecil. Kegiatan santunan terhadap anak yatim, seperti ditunjukkan pada Gambar 15.

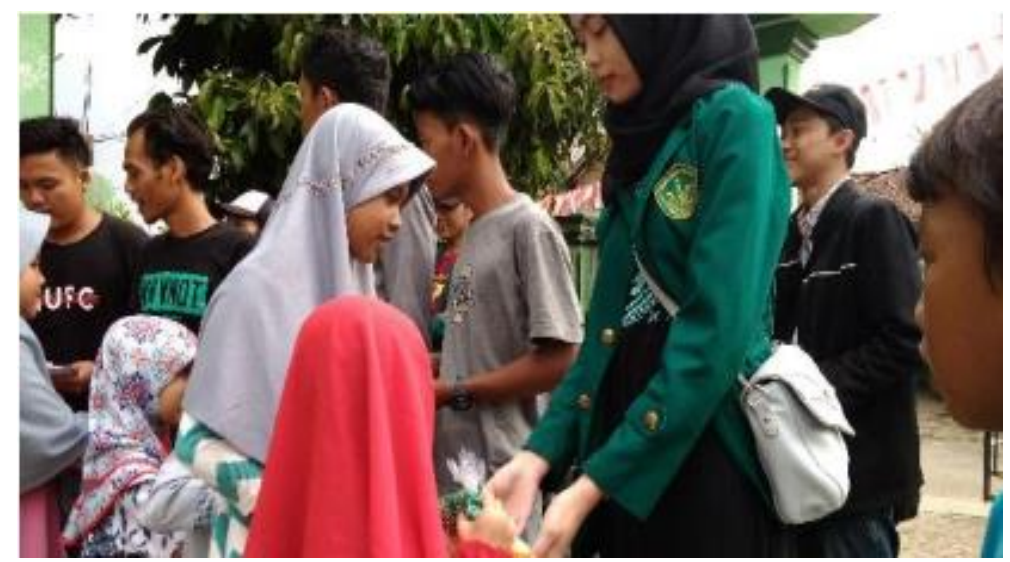

Gambar 15. Kegiatan Santunan Terhadap Anak Yatim

Gerakan Tanam Pohon

Kegiatan ini merupakan bentuk kerja sama dengan BPDAS Citarum-Ciliwung. Dilaksanakan pada hari Selasa, 04 September 2018 di Lapangan Bola Kampung Hegarsari. Kegiatan penghijauan ini dengan perlibatan Kepala Desa dan perangkat desa lainnya, seluruh Ketua RW dan RT di lingkungan Desa Cibeber I, dan Karang Taruna Kujang Desa Cibeber I. Tujuan penanaman 500 pohon sebagai salah satu upaya konservasi lahan dan mitigasi terhadap potensi bencana tanah longsor di Desa Cibeber I. Hal itu didasarkan kepada beberapa wilayah di desa yang berpotensi rawan terhadap bencana erosi. 
Penyerahan secara simbolis aktivitas penanaman pohon, seperti ditunjukkan pada Gambar 16.

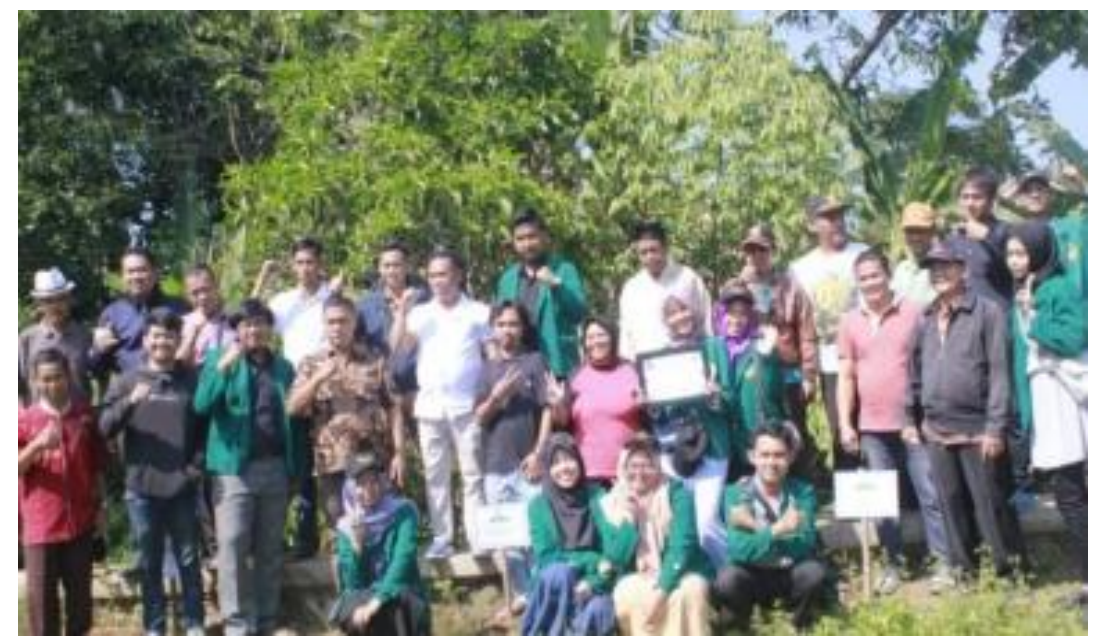

Gambar 16. Penyerahan Secara Simbolis Aktivitas Penanaman Pohon

Kegiatan ini terlaksana dengan capaian sebesar 100 persen. Sejumlah aktivitas saat penanaman pohon, seperti ditunjukkan pada Gambar 17.
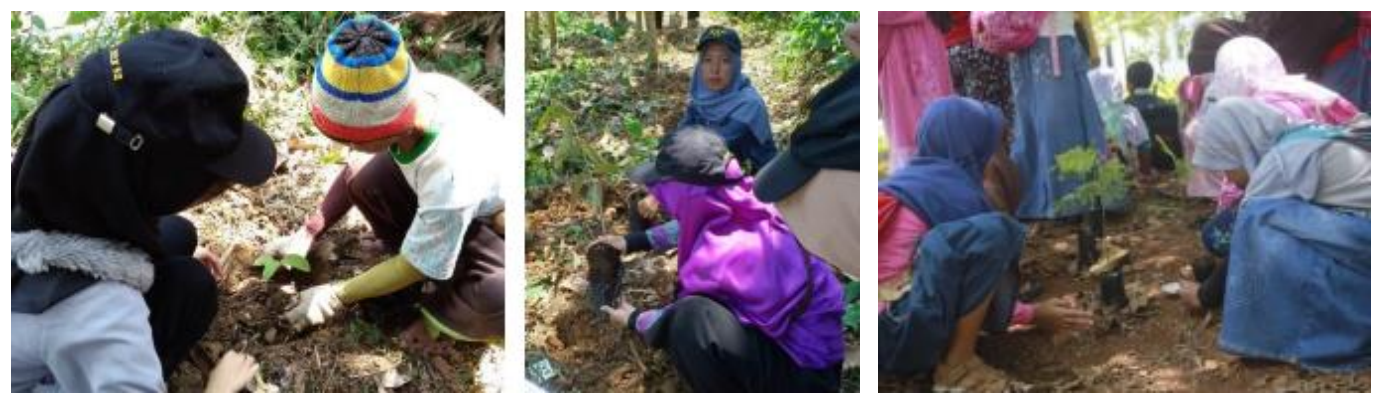

Gambar 17. Sejumlah Aktivitas saat Penanaman Pohon

Dampak jangka panjang terhadap kegiatan ini berupa keterciptaan Desa Cibeber I yang berdikari, hijau, dan asri.

\section{SIMPULAN}

Interkasi sosial oleh mahasiswa Kelompok $52 \mathrm{KKN}-\mathrm{TT}$ pada sebagian masyarakat Desa Cibeber I dengan berbagai jenis kegiatan merupakan upaya pemberdayaan terhadap masyarakat sasaran. Hal itu ditunjukkan dengan partsipasi masyarakat dalam bentuk penyiapan situasi dan kondisi, kerja sama, penyiapan tempat, dan masyarakat bekerja bersama. Di sisi lain, evaluasi juga telah dilakukan terdiri atas evaluasi terhadap proses dilakukan setiap pekan bersama tokoh-tokoh masyarakat dan keorganisasian yang terdapat di Desa Cibeber I, sedangkan evaluasi terhadap hasil dilaksanakan setelah kegiatan selesai setiap hari saat malam sebelum istirahat. Evaluasi hasil ditujukan untuk mengetahui sejauh mana program Kelompok $52 \mathrm{KKN}-\mathrm{TT}$ terlaksana.

Capaian program kerja dan dampak kegiatan pada masyarakat, yaitu (i) capaian pengajaran di Madrasah Ibtidaiyyah (MI) sebesar 100\% dengan manfaat jangka panjang berupa penghidupan kembali semangat belajar di sekolah; (ii) capaian penyelenggaraan bimbingan belajar sebesar 100\% dengan dampak berupa kebiasaan anak-anak untuk 
belajar bersama-sama dan pengurangan durasi bermain; (iii) capaian terhadap bantuan tenaga pada Pos Kesehatan Desa (Poskesdes) sebesar 80\% dengan dampak jangka pendek yang dapat diperoleh masyarakat berupa waktu berobat di posyandu menjadi lebih cepat dan proses yang lebih efisien. Dampak bagi kader dan petugas kesehatan berupa keterbantuan tugas kader dan petugas kesehatan dan efektivitas waktu yang digunakan untuk penanganan pasien; (iv) capaian terhadap keikutsertaan dalam kerja bakti kebersihan pada masjid sebesar $80 \%$ dengan dampak berupa timbul kesadaran pada masyarakat, bahwa kebersihan lingkungan masjid bukan hanya tugas DKM saja, tetapi juga tanggung jawab bersama; (v) capaian terhadap keikutsertaan pada pemberian vitamin A dan imunisasi sebesar $80 \%$ dengan dampak jangka panjang berupa pencegahan penyakit campak dikemudian hari dan pemantauan perkembangan tubuh balita; (vi) capaian terhadap keikutsertaan pada jalan sehat sebesar $80 \%$ dengan dampak berupa peningkatan sirkulasi darah, karena jantung berdebar dan efektif perkuat terhadap sistem kekebalan tubuh; (vii) capaian terhadap keikutsertaan pada penyuluhan pola hidup bersih dan sehat sebesar $90 \%$ dengan dampak terhadap para murid beroleh pengetahuan tentang perilaku hidup bersih dan sehat dan tepat waktu dan penerapannya di kehidupan sehari-hari; (viii) capaian terhadap keikutsertaan dalam pengajaran pada Taman Pendidikan Al-Quran sebesar 85\% dengan dampak terhadap beberapa anak sudah mulai dengan bacaan Al-Quran yang tartil sesuai dengan kaidah tajwid dan anak-anak sudah hafal 99 Asmaul Husna tanpa harus melihat kembali buku yang sebelumnya dilakukan; (ix) capaian terhadap pengajaran tentang tata cara dan praktik fiqh ibadah sebesar $95 \%$ dengan dampak terhadap anak-anaknya berupa kepahaman dalam praktik wudhu dan sholat sesuai ajaran Nabi Muhammad shollalloohu 'alaihi wa sallam dan paham tentang macam-macam perbedaan yang ada; $(x)$ capaian terhadap pengenalan dan pengobatan bekam sunnah sebesar $100 \%$ dengan dampak berupa timbul pemahaman masyarakat, bahwa pengobatan sunnah tidak kalah dengan pengobatan kimiawi, juga kesadaran dalam penjagaan kesehatan lebih penting daripada pengobatan; (xi) capaian terhadap keikutsertaan pada penyuluhan menabung sejak dini sebesar sebesar $100 \%$ dengan dampak berupa timbul kesadaran para murid tentang makna penting menabung untuk masa depan, terbiasa untuk hidup hemat, dan mampu untuk pengelolaan keuangan dimasa depan; (xii) capaian terhadap penyuluhan pemanfaatan sampah botol plastik sebesar $100 \%$ dengan dampak berupa pengenalan kreativitas untuk pengubahan botol plastik menjadi celengan, para murid dapat kelola limbah botol plastik menjadi barang yang lebih bernilai. Dampak jangka panjang yang dapat ditimbulkan berupa kebersihan lingkungan; (xiii) capaian terhadap pemanfaatan teknologi informatika berupa update dengan Google Maps untuk lokasi Kantor Desa Cibeber I sebesar 100\% dengan dampak berupa kemudahan warga pendatang atau wisatawan dalam tujuan Kantor Desa Cibeber I, termasuk sebagai langkah nyata untuk mewujudkan Desa Cibeber I sebagai desa potensial yang diarahkan menjadi Desa Pusat Pertumbuhan (DPP); (xiv) capaian terhadap keikutsertaan dalam acara peringatan dan perayaan HUT ke-73 RI sebesar 100\% dengan dampak berupa rasa kebersamaan dan solidaritas antar warga meningkat, tingkat nasionalis dan patriotisme di masyarakat Desa Cibeber I juga meningkat; dan (xv) capaian terhadap gerakan tanam pohon sebesar 100\% dengan dampak jangka panjang terhadap kegiatan ini berupa keterciptaan Desa Cibeber I yang berdikari, hijau, dan asri.

Di Desa Cibeber I masih banyak sekali fasilitas penunjang yang kurang, seperti fasilitas kesehatan, pendidikan, teknologi informatika, bahkan akses jalan pun sungguh sangat memprihatinkan. Tingkat pendidikan yang rendah, juga mempersempit peluang yang sebenarnya sangat cukup tinggi. Perekonomian masyarakat tidak dapat berkembang dengan maksimal, apabila sumberdaya manusia yang dimiliki tidak 
berkembang pula. Sumberdaya manusia tidak dapat berkembang apabila tidak terdapat fasilitas yang cukup memadai untuk pengembangan bakat dan kemampuan masyarakat.

Untuk pemberdayaan perekonomian di Desa Cibeber I dalam upaya peningkatan taraf hidup masyarakat, kelompok $52 \mathrm{KKN}-\mathrm{TT}$ merekomendasikan upaya-upaya yang perlu dilakukakan pemerintah, khususnya Pemerintah Daerah yang dalam hal ini secara langsung bertanggung jawab terhadap daerah otoritasnya.

1) Dalam hal pendidikan maupun kesehatan, pemerintah harus menambah dan melengkapi sarana dan prasarana menjadi lebih baik. Karena untuk meningkatkan tingkat pendidikan dan kesehatan takkan bisa dilakukan hanya dengan memotivasi masyarakat untuk menempuh pendidikan atau mensosialisasikan arti penting pendidikan dan kesehatan. Namun diperlukan fasilitas terlebih dahulu agar masyarakat dapat melaksanakan apa yang mereka butuhkan berkaitan dengan pendidikan dan kesehatan.

2) Perbaikan akses jalan, karena akses jalan Desa Cibeber I mengalami kerusakan, sehingga masyarakat harus mengendarai kendaraan dengan lambat, agar terjaga keselamatannya. Kerusakan tersebut menimbulkan kubangan air, jika turun hujan.

3) Pembuatan Tempat Pembuangan Sampah (TPS), karena Desa Cibeber I merupakan desa yang masih asri. Keindahan desa dirusak oleh sampah yang menumpuk di sekitar sungai. Upaya sosialisasi tentang TPS telah dilakukan kepada masyarakat, tetapi tanggapan yang diperoleh kurang baik. Ini kewajiban Pemerintah untuk melengkapi fasilitas TPS, sehingga kelak dengan pemberian ultimatum kepada masyarakat, agar buang sampah di tempat yang telah disediakan.

4) Dalam hubungannya dengan peserta $\mathrm{KKN}$, Pemerintah dapat menyempurnakan program mahasiswa KKN yang belum sesuai dan melanjutkan program yang belum dapat terlaksanakan dengan baik. Hendaknya pemerintah dan lembaga perguruan tinggi dapat bekerja sama dalam penyusunan kegiatan $\mathrm{KKN}$, agar kegiatan yang dilakukan dapat lebih sesuai dengan keadaan dan potensi daerah demi keterwujudan masyarakat yang mandiri dan sejahtera.

\section{REFERENSI}

Goeritno, A., Risamasu, F., Widodo, I., Mustafril, Syaiful, M., Prastowo, Mudiastuti, S., Suhatmono, \& Yahyah. (2003). Konsep penerapan teknologi tepat guna sebagai alternatif upaya mengatasi dampak kerusakan sumberdaya air (Concept of application of applied technology as an alternative in working out the effects of water resource damage). Bogor: Pascasarjana IPB.

Hikmat, R. H. (2001). Strategi Pemberdayaan Masyarakat, Cetakan ke-1. Bandung: Humaniora Utama Press (HUP).

Karsidi, R. (2002). Pemberdayaan masyarakat petani dan nelayan kecil. Makalah disampaikan pada disampaikan dalam Semiloka Pemberdayaan Masyarakat di Jawa Tengah dalam rangka Pelaksanan Otoda. Badan Pemberdayaan Masyarakat Jateng, di Semarang 4-6 Juni 2002 (pp. 1-11). 
Karsidi, R. (2007). Pemberdayaan masyarakat untuk usaha kecil dan mikro (Pengalaman Empiris di Wilayah Surakarta Jawa tengah). Jurnal Penyuluhan, 3(2), 136-145.

Kartasasmita, G. (1997). Pemberdayaan masyarakat: Konsep pembangunan yang berakar pada masyarakat. Jakarta: Bappenas.

Ma'mun, H. (2014, Maret, 5). Gambaran umum profil Desa Cibeber I. Retrieved March 5 , 2014 from http://desacibebersatu.blogspot.com/2014/03/gambaran-umum-profildesa-cibeber-i_6623.html?m=1 